\title{
Top 50 cited articles on fibromyalgia: A bibliometric analysis
}

\author{
Aysel Gurcan Atci \\ Baltalimani Metin Sabanci Bone and Joint Diseases Education and Research Hospital, \\ Department of Physical Therapy and Rehabilitation, Istanbul, Turkey
}

\begin{abstract}
Introduction. The purpose of this paper is to contribute to the literature by analyzing the top 50 cited articles on fibromyalgia with bibliometric methods.

Material and methods. First of all, fibromyalgia keyword was searched on PubMed and Google Scholar, and 50 articles with the highest citation index were selected from among the results. We then manually reviewed the contents of these articles by examining characteristics such as the number of citations, authorship, article title, year of publication, and topic categories.

Results. The top-50 cited articles were published in 18 journals. The most frequently cited journal was Arthritis and Rheumatism (16 articles) and the most common topic subject was treatment (17 articles), followed by pathophysiology (12 articles).

The 50 articles were reported from 8 different countries and the USA became the leading country with 38 articles published on this topic. The 50 articles we analyzed were originated from 20 different clinics and the clinic with the highest number of publishing became Department of Rheumatology, University of Kansas School of Medicinewhich is situated in US (5 articles).

Conclusion. The present study has produced a detailed list of the most-cited articles on fibromyalgia, which is the first such study in this field. This list makes it possible to recognize the classic articles on fibromyalgia as well as research trends and academic achievements in this field.
\end{abstract}

Keywords: fibromyalgia, bibliometric, analysis, physiotherapy and rehabilitation, rheumatology

\section{INTRODUCTION}

Fibromyalgia is a soft tissue rheumatism with chronic pain which has been frequently diagnosed in physiotherapy and rehabilitation and rheumatology clinics recently after the increased awareness. It is observed more frequently in women, and the rate of prevalence of fibromyalgia is between $0.2 \%$ and $6.6 \%$ when evaluated according to the diagnosis criteria all over the world (12). If the physician comes to mind during physical examination, fibromyalgia may escape the attention since it is asymptomatic except for pain and cognitive disorders. On the other hand, overdiagnosis / misdiagnosis are also frequently observed. Fibromyalgia is generally diagnosed after other diseases are eliminated and it does not present any radiological symptom. The diagnosis criteria are constantly revised. Its etiopathogenesis is not clearly known. Despite the great number of agent used in treatment and the intensive attempts, there is no recognized effective treatment agent for fibromyalgia patients.

In the recent years, there have been bibliometric analyses in many scientific areas in order to draw attention to valuable articles that are cited most. Bibliometric analysis is the analysis of the publications and the numerical relationship of these publications which issued by people or institutions of a certain place at a certain period and on a certain topic.

The purpose of this paper is to contribute to the literature by analysing the top 50 cited articles on fibromyalgia with bibliometric methods.

\section{MATERIAL AND METHOD}

This paper analyses the top 50 cited articles on fibromyalgia with bibliometric methods. First of all, We performed a title-specific search of the Web of 
Science, Pubmed, ScienceCitation Index and Google scholar database to identify most-cited articles in March 2019. We used "fibromyalgia and/or treatment" as our search terms without restricting publication dates. The top 50 most-cited articles were obtained and reviewed. We then manually reviewed the contents of these articles by examining characteristics such as the number of citations, all authors, first author's specialty, senior author, article title, year of publication, SCImago Journal Rank (SJR) (a prestige metric that represents a measure of scientific influence of journals and that constitutes the number of citations received by a journal and from which journals such citations made), journal source-normalized impact per paper (SNIP) (the ratio of a journal's citation impact and the degree of topicality of its subject field), country of origin, journal of publication, year of publication, citation count, and study category were recorded.. After that, the most cited articles were classified according to the subjects they handled.

Finally, the distribution of the top 50 cited articles is indicated in table. Data are presented using descriptive statistics, and no tests of statistical significance were performed. This study did not need to be reviewed by an ethics committee because it performed a bibliometric analysis of existing published studies and did not involve any additional human.

\section{RESULTS}

1,054 articles (at least 124 citations and above) were scanned concerning fibromyalgia and 50 of these were included in the evaluation process which were referred most. Of these articles, the highest citation was 9,304 while the lowest citation was 457 (Table 1).

TABLE 1. The top-50 cited articles on fibromyalgia

\begin{tabular}{|c|c|c|c|c|}
\hline Rank & $\begin{array}{l}\text { Number of } \\
\text { citation }\end{array}$ & First author & Journal, year & Title \\
\hline 1 & 9304 & Wolfe F & $\begin{array}{l}\text { Arthritis Rheum } \\
\text { 1990: } \\
\text { 33(2);160-172 }\end{array}$ & $\begin{array}{l}\text { The American College Of Rheumatology } 1990 \\
\text { Criteria For The Classification Of Fibromyalgia }\end{array}$ \\
\hline 2 & 2672 & Wolfe F & Arthritis Rheum 1995;38(1):19-28 & $\begin{array}{l}\text { The Prevalence And Characteristics Of } \\
\text { Fibromyalgia In The General Population }\end{array}$ \\
\hline 3 & 2523 & Wolfe F & $\begin{array}{l}\text { Arthritis Care Res (Hoboken) } \\
\text { 2010;62(5):600-610 }\end{array}$ & $\begin{array}{l}\text { The American College Of Rheumatology } \\
\text { Preliminary Diagnostic Criteria For } \\
\text { Fibromyalgia And Measurement Of Symptom } \\
\text { Severity }\end{array}$ \\
\hline 4 & 1867 & Burckhardt CS & $\begin{array}{l}\text { J Rheumatol } \\
\text { 1991;18:728-734 }\end{array}$ & $\begin{array}{l}\text { The fibromyalgia impact questionnaire: } \\
\text { development and validation. }\end{array}$ \\
\hline 5 & 1248 & $\begin{array}{c}\text { Gracely } \\
\mathrm{RH}\end{array}$ & $\begin{array}{l}\text { Arthritis Rheum, 2002; 46( 5):1333- } \\
1343\end{array}$ & $\begin{array}{l}\text { Functional Magnetic Resonance İmaging } \\
\text { Evidence Of Augmented Pain Processing in } \\
\text { Fibromyalgia }\end{array}$ \\
\hline 6 & 1135 & Yunus $\mathrm{M}$ & $\begin{array}{l}\text { Semin Arthritis Rheum 1981:11(1); } \\
\text { 151-171 }\end{array}$ & $\begin{array}{l}\text { Primary Fibromyalgia (Fibrositis): Clinical } \\
\text { Study Of } 50 \text { Patients With Matched Normal } \\
\text { Controls }\end{array}$ \\
\hline 7 & 1049 & Goldenberg DL & JAMA. 2004;292(19):2388-2395 & Management Of Fibromyalgia Syndrome \\
\hline 8 & 895 & Carville SF & Ann Rheum Dis 2008;67:536-541 & $\begin{array}{l}\text { EULAR Evidence-Based Recommendations } \\
\text { For The Management Of Fibromyalgia } \\
\text { Syndrome }\end{array}$ \\
\hline 9 & 803 & Bennett RM & $\begin{array}{l}\text { BMC Musculoskeletal Disorders } \\
\text { 2007;8:27 }\end{array}$ & $\begin{array}{l}\text { An Internet Survey Of 2,596 People With } \\
\text { Fibromyalgia }\end{array}$ \\
\hline 10 & 797 & Gracely RH & Brain 2004;127(4) 835-843 & $\begin{array}{l}\text { Pain Catastrophizing And Neural Responses } \\
\text { To Pain Among Persons With Fibromyalgia }\end{array}$ \\
\hline 11 & 793 & Wolfe F & J Rheumatol2011;38(6):1113-1122 & $\begin{array}{l}\text { Fibromyalgia Criteria And Severity Scales } \\
\text { For Clinical And Epidemiological Studies: A } \\
\text { Modification Of The ACR Preliminary Diagnostic } \\
\text { Criteria For Fibromyalgia } \\
\end{array}$ \\
\hline 12 & 790 & Russell IJ & Arthritis Rheum 1994 37(11):1593-601 & $\begin{array}{l}\text { Elevated Cerebrospinal Fluid Levels } \\
\text { Of Substance P In Patients With The } \\
\text { Fibromyalgia Syndrome }\end{array}$ \\
\hline
\end{tabular}




\begin{tabular}{|c|c|c|c|c|}
\hline Rank & $\begin{array}{l}\text { Number of } \\
\text { citation }\end{array}$ & First author & Journal, year & Title \\
\hline 13 & 784 & Busch AJ & $\begin{array}{l}\text { Cochrane Database Syst Rev. } \\
\text { 2002;(3):CD003786 }\end{array}$ & Exercise For Treating Fibromyalgia Syndrome \\
\hline 14 & 741 & Staud R & $\begin{array}{l}\text { Pain } \\
\text { 2001;91(1-2):165-175 }\end{array}$ & $\begin{array}{l}\text { Abnormal Sensitization And Temporal } \\
\text { Summation Of Second Pain (Wind-Up) In } \\
\text { Patients With Fibromyalgia Syndrome }\end{array}$ \\
\hline 15 & 735 & Crofford LJ & $\begin{array}{l}\text { Arthritis Rheum. } \\
\text { 2005;52(4):1264-73 }\end{array}$ & $\begin{array}{l}\text { Pregabalin for the treatmen omyedgia } \\
\text { syndrome: Results of a randomized, double- } \\
\text { blind, placebo-controlled trial }\end{array}$ \\
\hline 16 & 707 & Arnold LM & Arthritis Rheum. $2004 ; 50(9): 2974-84$ & \begin{tabular}{|lr}
$\begin{array}{l}\text { A double- } \\
\text { duloxe }\end{array}$ & $\begin{array}{c}\text { ter trial comparing } \\
\text { eatment of }\end{array}$ \\
omyalgia pa $\quad$ ts with or without major \\
depressive disorder
\end{tabular} \\
\hline 17 & 657 & Aaron LA & $\begin{array}{l}\text { Arch Intern Med. } 2000 \text { 24;160(2):221- } \\
\text { 7. }\end{array}$ & $\begin{array}{l}\text { Overlapping Conditions Among Patients With } \\
\text { Chronic Fatigue Syndrome, Fibromyalgia, and } \\
\text { Temporomandibular Disorder }\end{array}$ \\
\hline 18 & 623 & HudsonJI & Am J Med. 1992 ;92(4):363-7. & $\begin{array}{l}\text { Comorbidity of fibromyalgia with medical and } \\
\text { psychiatric disorders }\end{array}$ \\
\hline 19 & 620 & Crofford LJ & $\begin{array}{r}\text { 199 } \\
1994 ; 37(11): 1583-92 \\
\end{array}$ & $\begin{array}{ll}\text { Hypothalamic-pituitary-adrenal axis } \\
\text { perturba } & \text { omyalgia } \\
\end{array}$ \\
\hline 20 & 614 & Clauw DJ & JAMA. 2014:16;311(15):1547-55. & Fibromyalgia Clinical Review \\
\hline 21 & 613 & Branco JC & $\begin{array}{l}\text { Semin Arthritis Rheum. } 2010 \\
\text { Jun;39(6):448-53 }\end{array}$ & $\begin{array}{l}\text { Prevalence of Fibromyalgia: A Survey in Five } \\
\text { European Countries }\end{array}$ \\
\hline 22 & 603 & Mease P & J Rheumatol Suppl. 2005;75:6-21 & $\begin{array}{l}\text { Fibromyalgia syndrome: review of clinical } \\
\text { presenta pathogenesis, outcome measures, } \\
\text { and treatment. }\end{array}$ \\
\hline 23 & 591 & Yunus MB & $2007 ; 36(6): 339-56$ & $\begin{array}{l}\text { Fibromyalgia and Overlapping Disorders: } \\
\text { The Unifying Concept of Centr } \\
\text { Syndromes }\end{array}$ \\
\hline 24 & 586 & Goldenberg D & & \begin{tabular}{|l}
$\begin{array}{c}\text { A randomized, double-blind crossover trial of } \\
\text { xe } \\
\text { onyalgia }\end{array}$ \\
\end{tabular} \\
\hline 25 & 564 & Arnold LM & & Family s $\quad$ omyalgia \\
\hline 26 & 569 & Russell IJ & & $\begin{array}{l}\text { lerebr enic amine } \\
\text { metabolit omy } \\
\text { syndrome and rheumat }\end{array}$ \\
\hline 27 & 562 & Julien $\mathrm{N}$ & Pain. 2005;114(1-2):295-302. & $\begin{array}{l}\text { Widespread pain in fibromyalgia is related to } \\
\text { a deficit of endogenous pain inhibition }\end{array}$ \\
\hline 28 & 561 & Goldenberg DL & & $\begin{array}{l}\text { A randomized, controlled trial of amitriptyline } \\
\text { and naproxen in the treatment of patients } \\
\text { with fibromyalgia }\end{array}$ \\
\hline 29 & 557 & Kuchinad $A$ & J Neurosci. 2007 11;27(15):4004-7. & $\begin{array}{l}\text { Accelerated brain gray matter loss in } \\
\text { fibromyalgia patients: premature aging of the } \\
\text { brain? }\end{array}$ \\
\hline 30 & 555 & Lautenbachers & Clin J Pain. 1997 Sep;13(3):189-96. & $\begin{array}{l}\text { PossibleDeficiencies of Pain Modulation in } \\
\text { Fibromyalgia }\end{array}$ \\
\hline 31 & 552 & Arnold LM & $\begin{array}{l}\text { Psychosomatics2000; } \\
\text { 41(2):104-113 }\end{array}$ & $\begin{array}{l}\text { Antidepressant Treatment of Fibromyalgia: A } \\
\text { Meta-Analysis and Review }\end{array}$ \\
\hline 32 & 539 & Mccain GA & & $\begin{array}{l}\text { A controlled study of the effects of a } \\
\text { supervised cardiovascular fitness training } \\
\text { program on the manifestations of primary } \\
\text { fibromyalgia }\end{array}$ \\
\hline 33 & 537 & White KP & J Rheumatol. 1999;26(7):1570-6. & $\begin{array}{l}\text { The London Fibromyalgia Epidemiology } \\
\text { Study: the prevalence of fibromyalgia } \\
\text { syndrome in London, Ontario. }\end{array}$ \\
\hline
\end{tabular}




\begin{tabular}{|c|c|c|c|c|}
\hline Rank & $\begin{array}{l}\text { Number of } \\
\text { citation }\end{array}$ & First author & Journal, year & Title \\
\hline 34 & 534 & Moore RA & $\begin{array}{l}\text { Cochrane Database Syst Rev. } \\
\text { 2011:16;(3) }\end{array}$ & $\begin{array}{l}\text { Gabapentin for chronic neuropathic pain and } \\
\text { fibromyalgia in adults }\end{array}$ \\
\hline 35 & 531 & Kaplan KH & $\begin{array}{l}\text { Gen Hosp Psychiatry. 1993;15(5):284- } \\
\text { 9. }\end{array}$ & $\begin{array}{l}\text { The impact of a meditation-based stress } \\
\text { reduction program on fibromyalgia }\end{array}$ \\
\hline 36 & 529 & Koseka E & Pain. 1997;70(1):41-51. & $\begin{array}{l}\text { Modulatory influence on somatosensory } \\
\text { perception from vibration and heterotopic } \\
\text { noxious conditioning stimulation (HNCS) in } \\
\text { fibromyalgia patients and healthy subjects }\end{array}$ \\
\hline 37 & 527 & Arnold LM & Pain. 2005 15;119(1-3):5-15. & $\begin{array}{l}\text { A randomized, double-blind, placebo- } \\
\text { controlled trial of duloxetine in the treatment } \\
\text { of women with fibromyalgia with or without } \\
\text { major depressive disorder }\end{array}$ \\
\hline 38 & 524 & Grossman P & $\begin{array}{l}\text { PsychotherPsychosom. } \\
\text { 2007;76(4):226-33 }\end{array}$ & $\begin{array}{l}\text { Mindfulness Training as an Intervention for } \\
\text { Fibromyalgia: Evidence of Postintervention } \\
\text { and 3-Year Follow-Up Benefits in Well-Being }\end{array}$ \\
\hline 39 & 514 & Rossy LA & $\begin{array}{l}\text { Ann Behav Med. } 1999 \\
\text { Spring;21(2):180-91. }\end{array}$ & $\begin{array}{l}\text { A meta-analysis of fibromyalgia treatment } \\
\text { interventions }\end{array}$ \\
\hline 40 & 514 & Buchwald D & $\begin{array}{l}\text { Arch Intern Med. } 1994 \\
\text { 26;154(18):2049-53. }\end{array}$ & $\begin{array}{l}\text { Comparison of Patients With Chronic Fatigue } \\
\text { Syndrome, Fibromyalgia, and Multiple } \\
\text { Chemical Sensitivities }\end{array}$ \\
\hline 41 & 509 & Desmeules JA & Arthritis Rheum. 2003;48(5):1420-9. & $\begin{array}{l}\text { Neurophysiologic evidence for a central } \\
\text { sensitization in patients with fibromyalgia }\end{array}$ \\
\hline 42 & 507 & Vaerøy H & Pain. 1988;32(1):21-6. & $\begin{array}{l}\text { Elevated CSF levels of substance } P \text { and } \\
\text { high incidence of Raynaud phenomenon in } \\
\text { patients with fibromyalgia: new features for } \\
\text { diagnosis }\end{array}$ \\
\hline 43 & 503 & Bennett RM & Am J Med. 2003;114(7):537-45. & $\begin{array}{l}\text { Tramadol and acetaminophen combination } \\
\text { tablets in the treatment of fibromyalgia } \\
\text { pain: a double-blind, randomized, placebo- } \\
\text { controlled study }\end{array}$ \\
\hline 44 & 503 & Fregni F & Arthritis Rheum. 2006;54(12):3988-98. & $\begin{array}{l}\text { A randomized, sham-controlled, proof of } \\
\text { principle study of transcranial direct current } \\
\text { stimulation for the treatment of pain in } \\
\text { fibromyalgia }\end{array}$ \\
\hline 45 & 496 & Burckhardt CS & J Rheumatol. 1994;21(4):714-20. & $\begin{array}{l}\text { A randomized, controlled clinical trial of } \\
\text { education and physical training for women } \\
\text { with fibromyalgia. }\end{array}$ \\
\hline 46 & 493 & Mountz JM & $\begin{array}{l}\text { Arthritis Rheum. } \\
\text { 1995; } \\
\text { 38(7):926-938 }\end{array}$ & Fibromyalgia in women \\
\hline 47 & 493 & Epstein SA & Psychosoma & $\begin{array}{l}\text { Wychiatric Disorders in Patients } \\
\text { With Fibromyalgia: A Multicenter } \\
\text { Investigation }\end{array}$ \\
\hline 48 & 484 & Afflecka G & Pain. 1996;68(2-3):363-8 & $\begin{array}{l}\text { Sequential daily relations of sleep, pain } \\
\text { intensity, and attention to pain among } \\
\text { women with fibromyalgia }\end{array}$ \\
\hline 49 & 472 & Goldenberg DL & JAMA. 1987 22-29;257(20):2782-7. & $\begin{array}{l}\text { Fibromyalgia Syndrome. An emerging but } \\
\text { controversial condition }\end{array}$ \\
\hline 50 & 457 & Wolfe F & & $\begin{array}{l}\text { prospective, longitudinal, multicenter study } \\
\text { of service utilization and costs in fibromyalgia }\end{array}$ \\
\hline
\end{tabular}


TABLE 2. Journals with two or more of the top-50 cited articles on Fibromyalgia

\begin{tabular}{|c|l|c|c|c|}
\hline Rank & Journal & $\begin{array}{c}\text { Number of } \\
\text { articles }\end{array}$ & $\begin{array}{c}\text { SCI mago journal } \\
\text { rank (SJR) }\end{array}$ & $\begin{array}{c}\text { Source-normalized impact } \\
\text { per paper (SNIP) }\end{array}$ \\
\hline 1 & Arthritis and Rheumatism & 19 & 2,35 & 1,75 \\
\hline 2 & Pain & 6 & 2,67 & 2,03 \\
\hline 3 & $\begin{array}{l}\text { The Journal Of } \\
\text { Rheumatology }\end{array}$ & 5 & 2,16 & 1,431 \\
\hline 4 & $\begin{array}{l}\text { JAMA Archives of Internal } \\
\text { Medicine }\end{array}$ & 5 & 8,03 & 6,43 \\
\hline 5 & Cochrane Database Syst & 2 & 2,35 & 1,72 \\
\hline 5 & $\begin{array}{l}\text { The American Journal of } \\
\text { Medicine }\end{array}$ & 2 & 1,97 & 1,598 \\
\hline 5 & Psychosomatics & 2 & 0,970 & 0,681 \\
\hline 5 & Brain & 2 & 5,86 & 4,85 \\
\hline
\end{tabular}

The 50 articles which were referred most were published in 10 journals. In this context, the two mostly referred journals were Arthritis and Rheumatism and Pain, and 22 of these 50 articles were published in these journals (Table 2).

The 50 articles were reported from 8 different countries and the USA became the leading country with 38 articles published on this topic. The Canada come as the $2^{\text {nd }}$ (5 articles) and England, Swedish the $3^{\text {rd }}$ with 2 articles for each country. These three countries are the ones which published $76 \%$ of the articles which were referred most (Table 3).

TABLE 3. Countries of origin of the top-50 cited articles on Fibromyalgia

\begin{tabular}{|c|c|c|}
\hline Rank & Country & Number of articles \\
\hline 1 & USA & 38 \\
\hline 2 & Canada & 5 \\
\hline 3 & UK & 2 \\
\hline 3 & Switzerland & 2 \\
\hline 4 & Sweden & 1 \\
\hline 4 & Norway & 1 \\
\hline 4 & Portegual & 1 \\
\hline 4 & Germany & 1 \\
\hline
\end{tabular}

USA, The United States of America; UK, The United Kingdom

The 50 articles we analyzed were originated from 20 different clinics and the clinic with the highest number of publishing became Department of Rheumatology, University of Kansas School of Medicinewhich is situated in US ( 5 articles). The $2^{\text {nd }}$ clinic in terms of the number of publishing was Oregon Health Sciences University situated in USA, and the $3^{\text {rd }}$ was Department of Rheumatology, University Of Michigan situated in the US (Table 4). It is found out that 9 departments, in total, contributed to these publications and the leading department was Rheumatology (22 publications) while the $2^{\text {nd }}$ was psychiatry department (11 publications) and the $3^{\text {rd }}$ was physical therapy and rehabilitation department (4 publications).
TABLE 4. Institutions of origin of the first authors with three or more of the top-100 cited articles on fibromyalgia

\begin{tabular}{|c|l|c|}
\hline Rank & Institution & $\begin{array}{c}\text { Number of } \\
\text { article }\end{array}$ \\
\hline 1 & $\begin{array}{l}\text { University of Kansas School of } \\
\text { Medicine, USA }\end{array}$ & 5 \\
\hline 1 & Oregon Health Sciences University, USA & 5 \\
\hline 2 & University Of Michigan & 4 \\
\hline 2 & $\begin{array}{l}\text { University of Cincinnati College of } \\
\text { Medicine }\end{array}$ & 4 \\
\hline
\end{tabular}

USA, The United States of America; UK, The United

When authors of these publishing were analyzed, the first name on the list is Wolfe F. With 5 articles while the $2^{\text {nd }}$ name is Goldenberg DL'with 4 articles. LM Arnoldhas 4 articles for each (Table 5).

TABLE 5. People indicated as first authors of three or more of the top-100 cited articles on fibromyalgia

\begin{tabular}{|c|l|c|}
\hline Rank & First author & Number of articles \\
\hline 1 & Wolfe F & 5 \\
\hline 2 & Goldenberg DL & 4 \\
\hline 2 & LM Arnold & 4 \\
\hline
\end{tabular}

When we considered the contents of the 50 articles, we found out that 7 contents were discoursed and the most frequent topic was the factors which affected treathment (17 articles) while the second and the third most frequent topics were the affects of pathophysology (12 articles) and diagnostic criteria (5 articles) on survey (Figure 1).

Publication range of the 50 articles according to decades are given in the table (Graphic 1). 44 of the 40 articles were published in 1990s and 2000s. The oldest publication was made in 1981 and the newest one was reported in 2014. While the publications before 2000 focused more fibromyalgia diagnosis criteria, the publications made after 2000 dwelt on the treatment on this field. 


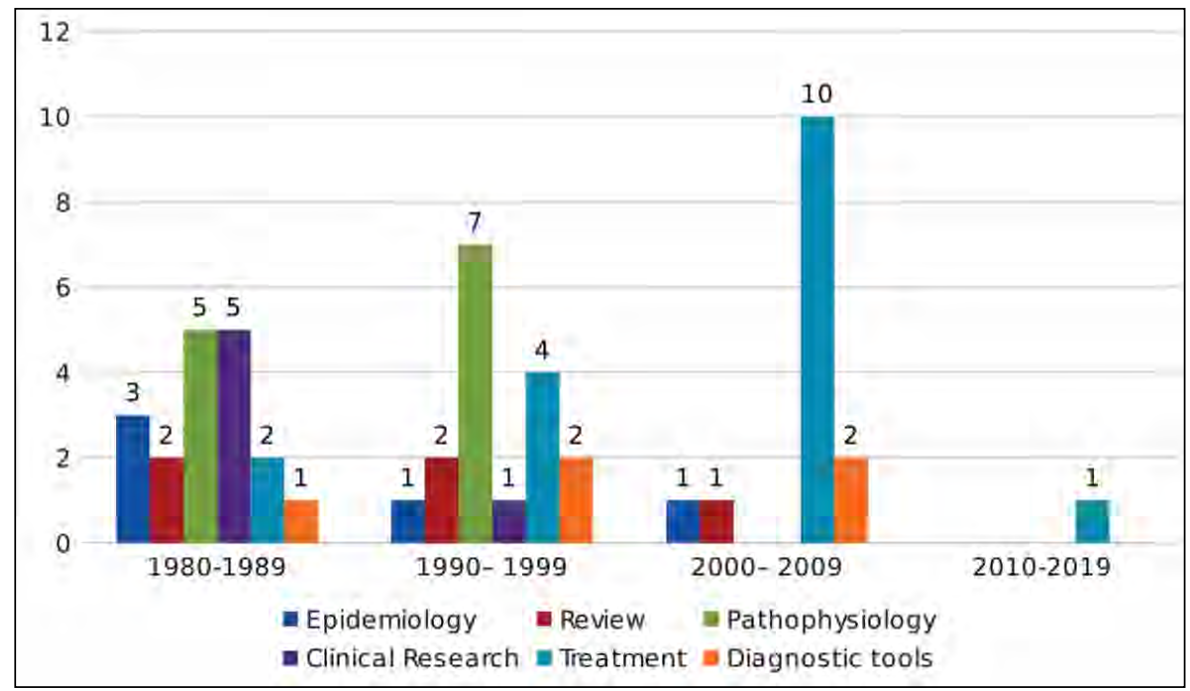

FIGURE 1. The number of publications of the top-100 cited articles on fibromyalgia according to topics

\section{DISCUSSION}

Research articles aim to reveal scientific results concerning any subject. On the other hand, the criterion that determines the attention drawn by these research articles is citation. Citation is defined as reference to another publication which was published before the referencing article. As a consequence, the number of citations from an article establishes the efficiency of that article in the world of science (13). Therefore, international publication activity evaluations are significant in defining scientifically developed countries. International data banks can be accessed on Thomson-Reuters, Institute of Scientific Information/Web of Science database (ISI), PubMed, Scopus and Google Scholar. Most countries carry out bibliometric studies in order to determine their place in contribution to universal science and in international publication rating. These studies help to get cumulative information on a specific topic between certain periods.

The first definition of bibliometric analysis was made by Pritchard in 1969 (13). The author claims that the first bibliometric study by content was the study carried out by Campbell in 1896 which was titled Theory of the National and International Bibliography (14).

The evaluation of frequently cited journals provides insight about the intense interest areas of a discipline as well as about the emerging areas. Literature reviews reveal that there are bibliographical analyses on many topics. Among these, there are various topics such as conventional and complementary medicine (4), anaesthesia reanimation (5), phys- iotherapy and rehabilitation (6), orthopaedics (7), spinal surgery (8), headache (9), neurorehabilitation (10) and psoriatic arthritis (11). However, literature reviews on fibromyalgia indicate that there is no extensive study on the top cited articles in this area.

Fibromyalgia mostly affects women, and is a complex-multifactorial disease without unknown etiopathogeny. It is a chronic widespread pain syndrome characterized by widespread musculoskeletal pain, sensitive areas specific to palpation, sleep disorders, fatigue and somatic and cognitive symptoms. In addition to main clinical symptoms, fibromyalgia patients also frequently show mood disorders, irritable colon syndrome, restless leg syndrome, morning stiffness, headache and genitourinary symptoms.

This study analyses the top 50 cited articles on fibromyalgia. These articles were published between 1981 and 2014. The citations were made mostly between 2000 and 2009 and from 21 publications. Among the top 50 cited articles, there are 4 articles that were published before 1990. The first 3 articles evaluated in this study had been published by Wolfe $\mathrm{F}$ et alia. The most cited article was cited 9304 times and was published in 1990 by Wolfe F et alia in Arthritis and Rheumatismjournal. The authors of this article attempted to develop diagnostic criteria for fibromyalgia which was known before 1986 but was generally ignored. As part of this attempt, 25 researches from 16 centres accepted 558 consecutive patients of which 293 were fibromyalgia patients. The study carried out on the combination of widespread pain and mild or higher sensitivity in 11 sensitive areas among 18 resulted in $88,4 \%$ sensitivity and $81,1 \%$ specificity. As a result, Wolfe stated that 
widespread pain and sensitivity in 11 specific sensitive areas among 18 are sufficient indicators for fibromyalgia diagnosis. At the diagnostic or classification level, the distinction between primary fibromyalgia and secondary-concomitant fibromyalgia (as defined in the text) is abandoned.

The second most cited article in this field was published in 1995 in Arthritis and Rheumatism journal. 3,006 randomized patients from Wichita, Kansas with no pain, no widespread pain and with widespread pain were included in this study. The study aimed to determine the prevalence and characteristics of fibromyalgia among the general population. 193 patients with widespread pain were interviewed and evaluated in detail. In consequence, it was concluded that the prevalence of fibromyalgia was more in women but was $2 \%$ for both sexes. Besides, the prevalence increased with age and peaked between 60 and 79. Characteristic features of fibromyalgia (pain threshold and symptoms) are similar in community and clinic populations, but overall severity, pain, and functional disability are more severe in the clinic population.

Similarly, the third most cited article was also carried out by Wolfe $\mathrm{F}$ et al. This study was published in 2010 in Arthritis Care \& Research journal. This multi-centre study carried out on 829 patients with fibromyalgia and a control group aimed to develop simple and practical clinical fibromyalgia diagnosis criteria which would not require sensitive area examination and would provide severity scale for characteristic fibromyalgia symptoms. The patients were subjected to a clinical assessment that measured the number of painful body areas and included widespread pain index. The results were used for guidance, development of the criteria and the creation of symptom severity (SS) scale. The most important diagnostic variables were widespread pain index (WPI), categorical scales for cognitive symp- toms, disturbed sleep quality, fatigue and the number of somatic symptoms. Categorical scales were later reviewed as symptom severity scale, and new criteria were created for fibromyalgia by combining symptom severity scale with WPI.

These top 50 articles demonstrate that treatment and pathophysiology are the most scrutinized topics while handling fibromyalgia. It is observed that 38 of the most cited 50 articles were published in the USA.Institutions in the USA have made great contributions to the development of research in the field of fibromyalgia, which can be explained by the large size of the American scientific community and the enormous financial resources available to it.

In this study, we attempted to eliminate potential criticisms concerning citation numbers. However, there can be certain limitations due to the nature of such analyses. For a very long time, there have been discussions whether citation numbers can indicate the value of an article. Nevertheless, the independent and primary variable is that there is a correlation between the number of citations and the quality of an article. Up to now, it has been observed that articles with high citation numbers are published especially in well-established journals with long publication histories

\section{CONCLUSION}

This study is important for the first bibliometric analysis of fibromyalgia, which has been a controversial subject for many years. This list makes it possible to recognize the classic articles on fibromyalgia as well as research trends and academic achievements in this field.

\section{Funding}

We received no financial support for the research and/or authorship of this article.

Conflict of interest: none declared

\section{REFERENCES}

1. Andersen J, Belmont J, Cho CT (2006). Journal impact factor in the era of expanding literature. J Microbiol Immunol Infect 39:436-43.

2. Garfield E, CawkellAE (1975). Citation analysis studies. Science 189:397.

3. Garfield E (1972) Citation analysis as a tool in journal evaluation. Science 178:471-9.

4. Tam WWS., Wong ELY, Wong FCY, Cheung AWL (2012). Citation classics in the integrative and complementary medicine literature: 50 frequently cited articles. Eur J Integr Med 4(1):77-83.

5. Baltussen A, Kindler $\mathrm{CH}$ (2004). Citation classics in anesthetic journals. AnesthAnalg 98:443-51.
6. Powell AJ, Conlee EM, Chang DG (2014). Three decades of citation classics: The most cited articles in the field of physical medicine and rehabilitation. PM R 6(9):828-40.

7. Kelly JC, Glynn RW, O'Briain DE et al (2010). The 100 classic papers of orthopaedic surgery: A bibliometric analysis. J Bone Joint Surg $\mathrm{Br}$ 92:1338-43

8. Steinberger J, Skovrlj B, Caridi JM, Cho SK (2015). The top 100 classic papers in lumbar spine surgery. Spine (Phila Pa 1976)15;40(10):740-7.

9. Park KM, Park BS, Park S, Yoon DY, Bae JS (2017) Top-100 Cited Articles on Headache Disorders: A bibliometric analysis. ClinNeurolNeurosurg157:40-45. 
10. Kreutzer JS, Agyemang AA, Weedon D et al (2017) The top 100 cited neurorehabilitation papers. NeuroRehabilitation 40(2):163174.

11. Berlinberg A, Bilal J, Riaz IB, Kurtzman DJB (2018). The 100 topcited publications in psoriatic arthritis: a bibliometric analysis. Int $\mathrm{J}$ Dermatol Oct 12. doi: 10.1111/ijd.14261.

12. Marques AP, Santo ASDE, Berssaneti AA, Matsutani LA, Yuan SLK(2017). Prevalence of fibromyalgia: literature review update. Rev Bras ReumatolEngl Ed 57(4):356-363.
13. Pritchard A. (1969). Statistical bibliography or bibliometrics? Journal of Documentation 25: 348-349.

14. Osareh $F(1996)$. Bibliometrics, citation analysis and co-citation analysis: A review of literature I, Libri, 46(3): 149-158.

15. Bernard AL, Prince A, Edsall $P$ (2000). Quality of life issues for fibromyalgia patients. Arthritis Care Res 13(1):42-50. 